\title{
エチレンジアミン四䣷酸の存在における 還元法を利用するモリブデンの定量*
}

林滋 彦**

エチレンジアミン四酢酸掞よび酒石酸塩の存在に拈いて，亚鉛アマルガムでモリブデンを定量的に還 元するのに適当な $\mathrm{pH}$ 究求めた結果， $\mathrm{pH} 4.0$ 扎よび 5.0 で還元するのが最もよく，還元時間 2 分で 3 価に定量的に還元することができる．との方法で還元した溶液に水酸化ナトリウム溶液を加えたのちイ ンジゴカーミン亚指示薬として赤血塩標準溶液で滴定してモリブデンを定量するてとができる.

\section{1 緒言}

エチレンジアミン四酶酸 (EDTA と略称する) を用い たモリブデンの定量法には, Feltham ら1のポーラロ グラフ法, Sousa2) のモリブデン酸カルシウムの沈殿を つくり,カルシウムをEDTA 溶液で滴定する間接定量 法, Lassner らの一定量の EDTA の存在でヒドラジ ンにより還元して 5 価モリブデンキレートをつくり，過 剩の EDTA 銅標準溶液で滴定する方法3 および 5 価 モリブデンキレートの呈色を利用する吸光光度法》など が知られている。

Pecsok ら5) は 5 洒小よび 6 洒モリブデンキレートに つきモリブデン対 EDTAの結合比はともに 2:1 であ ることを報告しているが，Lassner らの滴定法は 5 価モ リブデンキレートは銅キレートより安定であることを示 している.

著者は EDTA の存在のもとに各種の金属イオンを液 状金属アマルガムで還元して低い酸化数の金属キレート に変えることを試みた。一般にアマルガムによる還元は 酸性溶液で行なわれ，弱酸性ないしアルカリ性ではあま り行なわれていない。これは金属イオンおよびアマルガ ムから溶出する金属イオンが沈殿することなどの理由に よる.したがって，この酸性度における還元では，沈殿 の生成を阻止する適当な錯化㓮の存在が必要であり，吉 村6) はピロリン酸ナトリウムの存在のもとに $\mathrm{pH} 8$ で 亜鉛アマルガムによりモリブデンなどを還元している.

EDTAの存在のもとにこの酸性度で還元するときは， EDTA は金属イオンおよび溶出金属イオンとキレート

*エチレンジアミン四酢酸を利用する金属の分析法に 関する研究 (I )

** 福井大学学芸学部 : 福井市牧の島町
它つくるのでキレートが加水分解しないかぎり沈殿を生 ずることはない。

金属イオンには，その酸化還元電位に溶液の水素イオ ン濃度が関与するものと関与しないものとがある。一 方, EDTA が存在するとき酒化形および還元形金属 イオン濃度はキレートのみかけの生成定数によって規制 される.したがって, 後者では酸化還元電位に対する水 素イオン濃度の影響は間接的であり, 前者ではその上さ らに水素イオン濃度の影響が直接加わることになる.

後者の例に鉄イオンをとると，その酸化還元電位は

$$
E_{\mathrm{Fe}^{2+}-\mathrm{Fe}^{3+}}=E_{\mathrm{Fe}^{2+}-\mathrm{Fe}^{3+}}^{0}-\frac{R T}{F} \times \ln \frac{\left[\mathrm{Fe}^{3+}\right]}{\left[\mathrm{Fe}^{2+}\right]}
$$

2 価および 3 価鉄キレートの生成定数として次の值》が 与えられている. EDTA を $\mathrm{H}_{4} \mathrm{Y}$ で表わせ㳖,

$$
\begin{aligned}
& K_{\mathrm{FeY}^{2-}}^{\mathrm{Fe}^{2+}}=\frac{\left[\mathrm{FeY}^{2-}\right]}{\left[\mathrm{Fe}^{2+}\right]\left[\mathrm{Y}^{4-}\right]}=10^{14.33}, \\
& K_{\mathrm{FeY}^{-}}^{\mathrm{Fe}^{3+}}=\frac{\left[\mathrm{FeY}^{-}\right]}{\left[\mathrm{Fe}^{3+}\right]\left[\mathrm{Y}^{4-}\right]}=10^{25.1}
\end{aligned}
$$

2 価および 3 価の鉄イオン濃度を求めて前式に代入する 之,

$$
\begin{aligned}
E_{\mathrm{Fe}^{2+}-\mathrm{Fe}^{3+}} & =E_{\mathrm{Fe}^{2+}-\mathrm{Fe}^{3+}}^{0}-\frac{R T}{F} \times \ln \frac{\left[\mathrm{FeY}^{-}\right]}{\left[\mathrm{FeY}^{2-}\right]} \times \frac{K_{\mathrm{FeY}^{2-}}^{\mathrm{Fe}^{2+}}}{K_{\mathrm{FeY}}^{\mathrm{Fe}^{3+}}} \\
& =E_{\mathrm{Fe}^{2+}-\mathrm{Fe}^{3+}}^{0} \frac{R T}{F} \times \ln 10^{-10.77} \times \frac{\left[\mathrm{FeY}^{-}\right]}{\left[\mathrm{FeY}^{2-}\right]}
\end{aligned}
$$

$\left[\mathrm{FeY}^{2-}\right]=\left[\mathrm{FeY}^{-}\right]$のとき，

$$
E_{\mathrm{Fe}^{2+}-\mathrm{Fe}^{3+}}=E_{\mathrm{Fe}^{2+}-\mathrm{Ee}^{3+}}^{0}+\frac{R T}{F} \times \ln 10^{10.77}
$$

これは $\mathrm{FeY}^{2-}, \mathrm{FeY}^{-}$間の標準酸化還元電位を示す8). すなわち，EDTA の存在では鉄イオンの酸化還元電位 


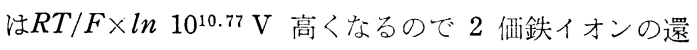
元力は強くなり9， 3 価鉄イオンの還元は困難になる. EDTA の存在による酸化還元電位の変化は酸化形およ び還元形イオンキレートの生成定数の大小で決定され， 還元形イオンキレートの方が安定なときは電位は低くな るので還元は容易になる。

前者の例としてバナジルイオン崖とると， EDTA の 存在における酸化還元電位は次式で表わされる.

$$
\begin{aligned}
\mathrm{V}^{3+}+\mathrm{H}_{2} \mathrm{O}= & \mathrm{VO}^{2+}+2 \mathrm{H}^{+}+e \\
E_{\mathrm{V}^{3+}-\mathrm{VO}^{2+}=} & E_{\mathrm{V}^{3+}-\mathrm{VO}^{2+}-\frac{R T}{F}}^{0} \\
& \times \ln \frac{\left[\mathrm{VOY}^{2-}\right]}{\left[\mathrm{VY}^{-}\right]} \times \frac{K_{\mathrm{VY}}^{\mathrm{VY}^{+}}}{K_{\mathrm{VOY}^{2-}}^{\mathrm{VO}^{2+}}} \times\left[\mathrm{H}^{+}\right]^{2}
\end{aligned}
$$

3 価バナジウム打よびバナジルキレートの生成定数の対 数值はそれぶれ 25.9 㐨よび 18.777)であり, [VOY ${ }^{2-}$ ] [VY-]とすると，

$$
E_{\mathrm{V}^{3+}-\mathrm{VO}^{2+}}=E_{\mathrm{V}^{3+}-\mathrm{vO}^{2+}}^{0}-\frac{R T}{F} \times \ln 10^{7.13} \times\left[\mathrm{H}^{+}\right]^{2}
$$

同一水素イオン濃度に执いて法, 笔位が $R T / F \times \ln 10^{7.13}$ $\mathrm{V}$ 低く交るのでバナジルイオンの還元は EDTA が存在 するときの方が容易でる。しかし，水素イオン濃度が 低くなると EDTAが存在しても還元は困難になる。

金属アマルガムについても溶出イオンはキレートをつ くってイオン濃度が低く尔るのでての電位は高くなる。 また，溶液の水素イオン濃度が低くなるにつて，みか けの生成定数が大きなって電位は高くなる.

したがって，還元時の溶液の水素イオン濃度，金属ア マルガムの種類および還元時間さ適当に選択することに より，金属イオン任意の低酸化数金属キレートに変え うることが尔想される。

著者注 EDTAの存在に出いて西鉛アマルガムだモり ブデンを還元するこに在試み，還元時の $\mathrm{pH} 4.0$ および 5.0 亿おいて短時間で 3 洒に定量的に還元でき，アルカ リ性にして赤血程標準溶液で滴定して定量することがで きた.

\section{2 試薬および装置}

モりブデン標準溶液： $450 〜 500^{\circ} \mathrm{C}$ で恒量にした三酸 化モリブデンを精ひょうし， $2 N$ 水酸化ナトリウム溶液 を滴加して溶解する. $2 N$ 塩酸で中和し, 水を加えて定 容にして $0.1 ， 0.05$ 打よび $0.03 M$ 溶液を調製した。

緩衝溶液 $: \mathrm{pH} 3.0$ の溶液は酢酸ナトリウム $27 \mathrm{~g}$ 苍 水に溶解し, $6 N$ 塩酸を加えて $\mathrm{pH}$ メーターにより $\mathrm{pH}$ 3.0 亿調節し, 全容を $500 \mathrm{~m} l$ にした. $\mathrm{pH} 4.0$ ないし 6.0 の溶液は酢酸ナトリウム $19 \mathrm{~g}$ 邑水に溶解し, 酷酸
を加えてそれぞれ所要の $\mathrm{pH}$ 亿調節し, 全容を $500 \mathrm{ml}$ そした. 以下 $\mathrm{pH} 7.0$ 打よび 8.0 の溶液は第一リン酸 カリウム $13.6 \mathrm{~g}$ から, $\mathrm{pH} 9.0$ の溶液はホウ砂 $15.8 \mathrm{~g}$ と第一リン酸カリウム $1.3 \mathrm{~g}$ から, $\mathrm{pH} 10.0$ の溶液は ホウ酸 $6.2 \mathrm{~g}$ と塩化カリウム $7.4 \mathrm{~g}$ から, $\mathrm{pH} 11.0$ 拐 よび 12.0 の溶液は第二リン酸ナトリウム $13.5 \mathrm{~g}$ から 上にのべた方法で水酸化ナトリウム溶液によりそれぞれ 所要の $\mathrm{pH}$ に調節し, 全容を $500 \mathrm{ml}$ にした.

酒石酸塩緩衝溶液 (酒石酸溶液と略称する) : 上にのべ た緩衝溶液と同組成同濃度でしかも $\mathrm{pH} 3.0$ および 4.0 の溶液は酒石酸ナトリウムで $0.25 M, \mathrm{pH} 5.0$ の溶液 は同じく $0.5 M$, また, $\mathrm{pH} 6.0$ 以上の溶液はロッシェ ル塩で 0.5 または $1 M$ になるように調製した。

EDTA 溶液 : エチレンジアミン四酢酸二ナトリウム 塩で $0.1 M$ 溶液を調製した。な扔， $\mathrm{pH} 6.0$ 以上で使用 するときは酒石酸溶液と同しく緩衝溶液にすると便利で ある。

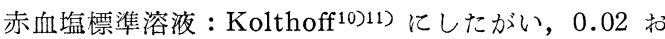
よび $0.05 N$ 溶液を調製した。

$10 N$ 水酸化ナトリウム溶液 : 煮沸して溶存酸素觉駆 出した蒝留水水酸化ナトリウム岩解して調製した。

$1 \%$ インジゴカーミン指示薬溶液 : バイエル製標準色 素のインジゴカーミンを水に溶解して調製し，1滴当り の赤血塩標準溶液の消費量をあらかじめ決定しておく.

亚鉛アマルガム：水銀を $0.1 M$ EDTA 溶液で扣扣っ て湯浴上で加熱する. 水銀 $100 \mathrm{~g}$ 亿対し亜鉛約 $4 \mathrm{~g}$ 觉加 えて十分に加熱溶解し， $0.1 M$ EDTA 溶液中に保存す る. 分液ロートで固状アマルガムを分離して使用した。

水素: $20 \%$ 水酸化ナトリウム溶液党電解し，ピロガロ 一ル水酸化ナトリウム溶液就よび硫酸第一バナジウム溶 液で洗浄して使用した。

アマルガム還元器 : 容量 $300 \mathrm{ml}$ のものを使用した.

ヤマト製水平振卜ウ機 (振幅 $15 \mathrm{~cm}$, 振卜ウ数 100 回/ 36 秒)：還元条件を一定にするために還元器を横置きに 固定できるようにした振トウ機を使用した.

堀場製 $\mathrm{T}$ 形ガラス電極 $\mathrm{pH} メ$ メター.

$$
3 \text { 実験 }
$$

\section{$3 \cdot 1$ 実験操作}

還元器のアマルガム受器に溶存酸素を駆出した苲留水 を満たす. 還元器中に蒸留水*岁満たし, 枝管から水素

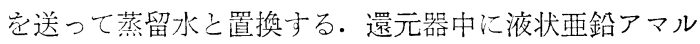
ガム約 $5 \mathrm{ml}$, モリブデン標準溶液, EDTA 溶液, 緩衝 溶液および $2 N$ 塩酸または $2 N$ 氷酸化ナトリウム溶液を 加えて所要の $\mathrm{pH}$ に調節するとともに全容を $45 \mathrm{ml}$ に する. 別にビーカー中で同じ混合溶液をつくり, 所要の $\mathrm{pH}$ に調節するために必要な $2 N$ 掹酸または $2 N$ 水酸化 ナトリウム溶液の添加量它㐫かじめ決定しておく. $\mathrm{pH}$ が高くなると還元中に沈殿を生ずるので，これを阻 止するために補助錯化剂として酒石酸溶液を加え, 緩衝

*溶存酸素を駆出しなくてよい. 
溶液をその量だけ減らして全容を $45 \mathrm{ml}$ にする. 還元器 を振卜ウ機に固定して一定時間振卜ウ還元する. アマル ガムを 3 回にわけて分離し, $10 N$ 水酸化ナトリウム溶液 をアルカリにつき 1.5 ないし $2 N$ になるように添加した のちインジゴカーミンを指示薬として赤血塩標準溶液で 滴定する. 同じ方法で白試験を行ない，指示薬に対する 赤血塩標準溶液の消費量とをあわせ差引いて滴定值を決 定した.

\section{$3 \cdot 2$ モリブデンの還元}

3・2・1 pH の影響 上にのべた方法によりモりブ デン標準溶液 $5 \mathrm{~m} l$ に $0.1 M$ EDT A 溶液 $20 \mathrm{~m} l$ を加え て亜鉛アマルガムで 30 分間還元する操作を $\mathrm{pH} 3.0$ な いし 12.0 で行ない, 赤血塩標準溶液で滴定した結果を Table I に示した. なお, pH 7.0 以上では沈殿の生成 を阻止するため $0.5 M$ 酒石酸溶液 $5 \mathrm{ml}$ を全容 $45 \mathrm{ml}$ 中 に含めた.

Table I 還元時の $\mathrm{pH}$ と滴定值

\begin{tabular}{|c|c|c|}
\hline 罯元時の $\mathrm{pH}$ & 添加した錯化剂 & 滴定值 $(\mathrm{m} l)$ \\
\hline 3.0 & EDTA & 18.80 \\
\hline 4.0 & " & 19.33 \\
\hline 5.0 & " & 19.39 \\
\hline 6.0 & " & 19.19 \\
\hline 7.0 & EDTA+酒石酸 & 17.99 \\
\hline 8.0 & " & 15.19 \\
\hline 9.0 & " & 0.80 \\
\hline 10.0 & " & 0.32 \\
\hline 11.0 & " & 0.21 \\
\hline 12.0 & " & 0.00 \\
\hline \multicolumn{3}{|c|}{$0.02730 M \mathrm{Na}_{2} \mathrm{MoO}_{4} 5 \mathrm{ml}$, 還元時間 30 分, $0.02114 N \mathrm{~K}_{3} \mathrm{Fe}(\mathrm{CN})_{6}$} \\
\hline 計算上の滴定做 & \multicolumn{2}{|c|}{$\begin{array}{l}3 \text { 価まで還元した場合 } 19.37 \mathrm{ml} \\
5 \text { 価まで還元した場合 } 6.46 \mathrm{~m} l\end{array}$} \\
\hline
\end{tabular}

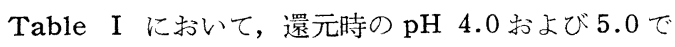
モリブデンは 3 価に定量的に還元されるが， $\mathrm{pH}$ が高く なるにしたがって還元率は低下し， $\mathrm{pH} 12.0$ では全く 還元されない.

モリブデン酸イオンの還元には溶液の水素イオン濃度 が強く影響し, 水素イオン濃度が低くなるにしたがって 還元は困難になる。緒言で述べたようにこのことは EDTA が存在する場合にもあてはまり，pH 4.0 ない し 12.0 の滴定值はこのことを示している.しかし， $\mathrm{pH}$ 3.0 の滴定值は pH 4.0 のそれより小さく, pH 3.0 で は還元が困難なことを示している.これは 3 洒ないし 5 価モリブデンキレートの安定度に差異があることによる ものも予想されるが，これらキレートの化学的性質が明 らかでない現状では安易に結論することはできない。な
お, 滴定時のアルカリ度が $1 N$ 以下では指示薬の変色が 不鋭敏なため $1.5 \mathrm{~N}$ 以上に寺ることが必要である。 ま た， 3 価モりブデンは空気中の酸素により容易に酸化さ れるので, 滴定中還元器内に空気が流入しないように注 意しなければならない。

$\mathbf{3 \cdot 2 \cdot 2}$ EDTA の添加量 $3 \cdot 2 \cdot 1$ における EDTA の添加量は対モリブデンのモル比で約 15 倍量であった が，EDTA の添加量を変えた場合，還元状態によ゙のよ うな影響を抢よぼすかにつき検討した。還元時の $\mathrm{pH}$ 5.0 とし, EDTA の添加量に応じて緩衝溶液を増減し て全容を $45 \mathrm{~m} l$ とし, 還元時間, 滴定方法など前に述べ た方法にしたがった、結果を示すと Table II のように なる・

Table II EDTA 添加量と還元状態

\begin{tabular}{ccc}
\hline EDTA 添加量(EDTA/Mo モル比) & 滴定値 $(\mathrm{ml})$ & 還元液の色 \\
\hline 1 & 14.52 & 茶加色 \\
2 & 15.04 & 茶緑 \\
3 & 15.29 & 緑 "色 \\
4 & 15.30 & " \\
8 & 15.31 & " \\
16 & 15.30 & " \\
\hline
\end{tabular}

$0.05100 \mathrm{M} \mathrm{Na} \mathrm{MoO}_{4} 5 \mathrm{ml}, \mathrm{pH} 5.0$, 還元時間 30 分, $0.05003 N \quad \mathrm{~K}_{3} \mathrm{Fe}(\mathrm{CN})_{6}$

計算上の滴定値 $\left\{\begin{array}{l}3 \text { 価まで還元した場合 } 15.29 \mathrm{~m} l \\ 5 \text { 価まで邉元した場 } 5.10 \mathrm{~m} l\end{array}\right.$

3 価モリブデンキレートの結合比は $1: 1$ であり，そ の生成定数は业鉛キレートのそれより大であると仮定す れば，EDTA の添加量がモル比で 2.5 倍量のときモり ブデンおよび溶出亜鉛イオンに当量の EDTA が存在す るから添加量が 2.5 倍量以下では遊睢の亜鉛イオン濃度 が高くなり，その電位が低くなって還元が不完全になる ものと考えられる. Table II から EDTA 添加量をモ ル比で 3 倍量にすれば十分なことがわかる.

次に, EDTA の添加量をモル比で 3 倍量として $\mathrm{pH}$ と還元率の関係につき検討した. EDTA の添加量が異 なることと $\mathrm{pH} 6.0$ 以上で酒石酸溶液を添加したほかは $3 \cdot 2 \cdot 1$ の方法と同じく操作した. 結果を Table III に 示した.なお，還元率は 3 洒に還元されるものとして滴 定值から算出した.

結果は Table I と同じ傾向を示している. 酒石酸溶 液を添加しないとき $\mathrm{pH} 6.0$ 以上で生ずる沈殿はキレー 卜の加水分解生成物之思われる. Table I では pH 7.0 以上で酒石酸溶液を添加したことから，過剰の EDTA は加水分解を抑制することがわかる. キレートの加水分 解定数は金属水酸化物の溶解積とキレートの生成定数と 
Table III 還元時の $\mathrm{pH}$ と滴定值

\begin{tabular}{|c|c|c|c|c|}
\hline 還元時の $\mathrm{pH}$ & 添加錯化剂 & 滴定值 $(\mathrm{m} l)$ & 還元率(\%) & 嚐元液の色 \\
\hline 3.0 & EDTA & 14.83 & $97.0_{0}$ & 茶緑色 \\
\hline 4.0 & " & 15.30 & $100.0_{6}$ & 緑色 \\
\hline 5.0 & " & 15.29 & $100.0_{n}$ & " \\
\hline 6.0 & EDTA+酒石酸 & 14.64 & $95.7_{4}$ & 茶緑色 \\
\hline 7.0 & " & 13.83 & $90.4_{5}$ & 茶かっ色 \\
\hline 8.0 & " & 11.98 & $78.3_{5}$ & $"$ \\
\hline 9.0 & " & 0.83 & $5.4_{2}$ & " \\
\hline 10.0 & " & 0.31 & $2.0_{2}$ & 淡黄色 \\
\hline 11.0 & " & 0.04 & $0.2_{3}$ & " \\
\hline 12.0 & " & 0.00 & $0.0_{0}$ & 無 \\
\hline
\end{tabular}

$0.05100 M \mathrm{Na}_{2} \mathrm{MoO}_{4} 5 \mathrm{ml}$, 還元時間 30 分, $0.05003 \mathrm{~N} \mathrm{~K}_{3} \mathrm{Fe}(\mathrm{CN})_{6}$

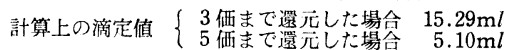

の積の逆数で表わされ(2)，3 価モリブデンキレートの生 成定数は大きいことが推祭さ机るので*，3価モリブデ ン水酸化物の溶解積は非常に小さいことが想像される.

Table I および III から，pH 4.0 または 5.0 およ び 12.0 と同一還元条件で一定状態に定量的に還元され る金属がモりブデンと共存するときは示差滴定により両 者を定量できることがわかる.

$3 \cdot 2 \cdot 3$ 酒石酸の添加量 $\quad \mathrm{pH} 6.0$ 以上では酒石酸 溶液を添加したが，酒石酸が還元におよぼす影響につき 検討した. EDTA の添加量は 3 倍量とし, 酒石酸溶液 の添加量を変えて還元してみた. 酒石酸溶液の添加量だ け緩衝溶液を減らして全容を $45 \mathrm{ml}$ とし，還元時間は $\mathrm{pH} 4.0$ および 5.0 では 2 分, そのほかの $\mathrm{pH}$ では 30 分とし，ほかの操作はすでに述べた方法にしたがい，結 果を Table IV 抢よ゙ V に示した.

$\mathrm{pH} 4.0$ および 5.0 では 20 ないし 30 倍量, $\mathrm{pH} 6.0$ では 60 ないし 80 倍量酒不酸溶液を添加すればそれぞれ 還元時間 2 分および 30 分で 3 価に定量的に還元でき る. pH 7.0 以上でも添加量を增すにしたがって還元率 は高くなり, pH 9.0 以上ではその度合は特に著しい。

$3 \cdot 2 \cdot 4$ 還元時間 還元時間と還元状態との関係に つき検討した。 pH 4.0 および 5.0 で EDTA および酒 石酸の添加量をモル比でそれぞれ 3 倍量および 30 倍量 とし，結果を Table VI に示した.

還元時間 2 分で 3 枆に䇥量的に還元できる.なお， pH 5.0 でモル比で 3 倍量の EDTAを添加し, 酒石酸 溶液を加えないときは還元時間 3 分を要した。

* キレートの生成定数は同一金属では酸化数が高いほ ど大きいが，才キシカチオンキレートの生成定数は 小さく13)，たとえば，チ夕ニウム托よびバナジウム では 3 価キレートの生成定数は 4 価のそれより大き (7).
Table IV 酒石酸添加量と還元状態 (その 1)

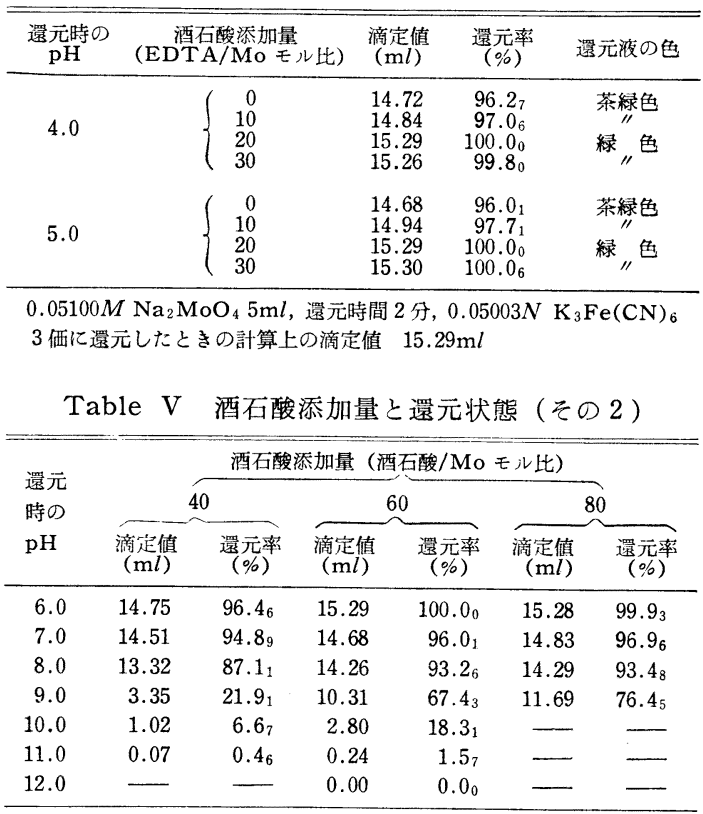

$0.05100 M \mathrm{Na}_{2} \mathrm{MoO}_{4} 5 \mathrm{ml}$, 還元時間 30 分, $0.05003 N \mathrm{~K}_{3} \mathrm{Fe}(\mathrm{CN})_{6}$. 3 価罯元したときの計算上の滴定值 $15.29 \mathrm{~m} l$

Table VI 還元時間と還元状態

\begin{tabular}{|c|c|c|c|c|}
\hline \multirow{3}{*}{$\begin{array}{c}\text { 還元時間 } \\
\text { （分） }\end{array}$} & \multicolumn{4}{|c|}{ 遠 元 時 $の ~ p H$} \\
\hline & \multicolumn{2}{|c|}{$\underbrace{4.0}$} & \multicolumn{2}{|c|}{5.0} \\
\hline & 滴定值 $(\mathrm{m} l)$ & 還元率(\%) & 滴定值 $(\mathrm{m} l)$ & 還元率 (\%) \\
\hline 1 & 14.29 & $93.4_{1}$ & 14.81 & $96.8_{6}$ \\
\hline 2 & 15.26 & 99.80 & 15.28 & $99.9_{3}$ \\
\hline 3 & 15.28 & $99.9_{3}$ & - & - \\
\hline 4 & 15.28 & $99.9_{3}$ & 15.31 & $100.1_{3}$ \\
\hline 30 & 15.30 & $100.0_{6}$ & 15.31 & $100.1_{3}$ \\
\hline 120 & 15.29 & $100.0_{0}$ & 15.28 & $99.9_{3}$ \\
\hline
\end{tabular}

$0.05100 \mathrm{M} \mathrm{Na}{ }_{2} \mathrm{MoO}_{4} 5 \mathrm{ml}, 0.05003 \mathrm{~N} \mathrm{~K}_{3} \mathrm{Fe}(\mathrm{CN})_{6}$.

3 価记還元したときの計算上の滴定值 $15.29 \mathrm{~m} l$

\section{$3 \cdot 3$ 分析例}

EDTA および酒石酸の添加量をそれぞれ 3 倍量およ び 20 倍量としていろいろ異なった量のモりブデンにつ き定量を試み，結果を Table VII に示した。

Table VII モリブデンの定量

\begin{tabular}{|c|c|c|c|c|}
\hline $\begin{array}{c}\text { Mo の採取量 } \\
\text { (mg) }\end{array}$ & $\begin{array}{c}\text { 還元時の } \\
\mathrm{pH}\end{array}$ & $\begin{array}{l}\text { 還元時間 } \\
(\text { 分) }\end{array}$ & $\begin{array}{l}\text { 定量值 } \\
(\mathrm{mg})\end{array}$ & $\begin{array}{l}\text { 誤 差 } \\
(\mathrm{mg})\end{array}$ \\
\hline $\begin{array}{c}49.5 \\
\prime \prime\end{array}$ & $\begin{array}{l}4.0 \\
5.0\end{array}$ & $\begin{array}{l}30 \\
\prime \prime\end{array}$ & $\begin{array}{l}49.5 \\
49.4\end{array}$ & $\begin{array}{l} \pm 0.0 \\
-0.1\end{array}$ \\
\hline $\begin{array}{c}26.2 \\
\text { "I } \\
\text { " }\end{array}$ & $\begin{array}{c}4.0 \\
5.0 \\
\prime \prime\end{array}$ & $\begin{array}{l}\text { " } \\
4 \\
4\end{array}$ & $\begin{array}{l}26.0 \\
26.1 \\
26.0\end{array}$ & $\begin{array}{l}-0.2 \\
-0.1 \\
-0.2\end{array}$ \\
\hline $\begin{array}{l}13.1 \\
\prime \prime\end{array}$ & $\begin{array}{l}4.0 \\
5.0\end{array}$ & "I & $\begin{array}{l}13.2 \\
13.1\end{array}$ & $\begin{array}{l}+0.1 \\
\pm 0.0\end{array}$ \\
\hline $\begin{array}{l}4.9 \\
11\end{array}$ & $\begin{array}{l}4.0 \\
5.0\end{array}$ & $\begin{array}{l}30 \\
\prime \prime\end{array}$ & $\begin{array}{l}4.9 \\
4.9\end{array}$ & $\begin{array}{l} \pm 0.0 \\
\pm 0.0\end{array}$ \\
\hline
\end{tabular}


硫酸溶液で 覀鉛アマルガムによりモリブデンを 3 価 に還元する 通常法では還元時間は 1 分以下でよく14), EDTA の存在で還元する方法は還元時間の点でわずか に劣るにすぎない，前に述べたように，モリブデンと共 存する金属によっては示差滴定により両者を定量しうる 可能性が認められることはこの還元法の一特徵である. なお，示差滴定による定量についてはおって検討する予 定である. る.

本実験に 終始協力された広田比呂子氏に 謝意さ表す

\section{交献}

1) R. D. Feltham, E. L. Martin : Anal. Chem., 25, 1935 (1953).

2) A. de Sousa : Anal. Chim. Acta, 12, 215 (1955).

3) E. Lassner, R. Scharf : Z. anal. Chem., 167, 114 (1959).

4) E. Lassner, R. Scharf : ibid., 168, 30 (1959).

5) R. L. Pecsok, D. T. Sawyer :J. Am. Chem. Soc., 78, 5496 (1956).

6) 吉村長蔵：日化，76，411（1955)

7) J. Bjerrum, G. Schwarzenbach, L. G. Sillen: "Stability Constants", Part I, p. 76 (1957), (The Chemical Society, London).

8) G. Schwarzenbach, J. Heller : Helv. Chim. Acta, 34, 576 (1951).

9) K. L. Cheng : Anal. Chem., 27, 1165 (1955).
10) I. M. Kolthoff, E. B. Sandell : “Textbook of Quantitative Inorganic Analysis”, p. 595 (1936).

11) I. M. Kolthoff, R. Belcher : "Volumetric Analysis”, Vol. 3, p. 236 (1957), (Interscience Publishers, Inc., New York).

12) F. J. Welcher : "The Analytical Uses of Ethylenediaminetetraacetic Acid", p. 7 (1957), (Van Nostrand Co., Inc., Princeton).

13) M. J. Cabell : Analyst, 77, 859 (1952).

14）大幸勇吉: “化学実験学”, 第 1 部, 分析化学 II, p. 30 (1942), (河出書房).

$$
\text { 放 }
$$

Reduction in the presence of ethylenediaminetetraacetic acid (EDTA) and titrimetric determination of molybdenum. (Application of ethylenediaminetetraacetic acid to the determination of metal. I.) Shigehiko Hayashi (Faculty of Liberal Arts, Fukui University)

The optimum $\mathrm{pH}$ giving the quantitative reduction of molybdenum with zinc amalgam in the presence of EDTA and tartrate was sought, and it was found that molybdenum could be reduced quantitatively to the tervalent state at $\mathrm{pH} 4.0$ and 5.0 by shaking with the reagent for 2 min. After an addition of sodium hydroxide solution to the reduced solution, molybdenum was determined by titration with a standard potassium ferricyanide solution using indigocarmine as an indicator.

(Received Jan. 13, 1962)

\title{
矩形波ポーラログラフによる微量マンガンの定量*
}

\author{
藤永 太一郎, 萩原 一芳**
}

\begin{abstract}
矩形波ポーラログラフによって微量のマンガン觉定量するため，数種の支持電解筫について検討した 結果，トリエタノールアミン觉用いる方法がもっともすぐれているてとを認め，乙れてついて基礎的な 検討觉行なった。、ンガンは $0.2 M$ トリタノールアミン, $0.5 M$ 水酸化アルカリ溶液中で, 空気觉吹 込みながら約 20 分間沸とう水中で加熱することにより 3 価となり，良好な還元波范示す. ピークは $-0.50 \mathrm{~V}$ (対 S. C. E.) 亿あらわれ， $1 \times 10^{-6} \sim 2 \times 10^{-5} M$ の範囲で検量線は直線となる. 銅は妨害す るが, $1 \times 10^{-5} M$ 以下の存在は許される.

本法を試薬級硫酸第二鉄アンモニウム中のマンガンの分析に適用して好結果觉得た。
\end{abstract}

\section{1 緒言}

マンガンのポーラログラフによる定量には，従来 $\mathrm{Mn}^{2+} \rightarrow \mathrm{Mn}$ の還元波を利用与る方法之，適当な錯化剂

* ポーラログラフ法による分析化学的研究 (第 41 報)

** 京都大学理学部化学教室 : 京都市左京区吉田本町
共存時において酸化し, $\mathrm{Mn}^{3+} \rightarrow \mathrm{Mn}^{2+}$ の還元波を利用 する方法とがよく知られている.

前者としては, 塩化カリウム，アンモニア-塩化アン モニウム，シアン化カリウムなどが検討されているが， いずれも半波電位が比較的負であり, 共存他元素の妨害 をらけやすい1)。 